\title{
Contents in brief
}

Extended contents

List of contributors

$\mathrm{vi}$

Advisory Board

$\mathrm{x}$

Editorial

xi

xii

1. Rochelle C. Dreyfuss

The challenges facing IP systems: researching for the future

2. Hans-W. Micklitz

The digital economy, digital society, and private law

3. Frauke Henning-Bodewig

Unfair competition law - an annex to IP law? A consumer protection law? A legal field in its own right?

4. Mark Findlay

Property abandoned? Rights, wrongs and forgetting Durkheim

5. Pedro Marcos Nunes Barbosa

The forsaken PTO: some observations on public policies concerning intellectual property law in Brazil

6. Séverine Dusollier

Intellectual property and the bundle-of-rights metaphor

7. Valeria Falce

Uses and abuses of database rights

Index 